\title{
Food Made of Organic Food as a Means of Sustainability in a Caring Economics
}

\author{
Klara Vaclavinkova \\ School of Business Administration in Karvina, Silesian University in Opava, Czech Republic
}

\begin{abstract}
Organic foods are currently among the new trends. Restaurant operators can use them as a means to enrich their offer. In the Czech Republic, organic agriculture is of great benefit in terms of agri-tourism operation. Agri-tourism also offers new business opportunities. Then, the article discusses the evaluation of the use of common applications bio-foods to supply it in restaurants and strengthens the economic stability of the company. The method used in this paper is empirical research, based on work with existing data, and by a descriptive way, the author draws conclusions. The conclusion part summarized the possibility of using organic products in gastronomy. The main issues addressed in the text are: Numbers of farmer focused on production of organic food has increased since 2001; The production of organic food increases; It is possible to use organic foods for enrichment menu in restaurants. The result is a recommendation on how to bring organic food to the customer in the form of specials on the menu, to inform him/her of their consumption positives and offer special deals with organic products.
\end{abstract}

Keywords: organic foods, agri-tourism, additives, propagation

\section{Gastronomy and Organic Food}

Gastronomy is now a discipline that deserves serious attention. The new and progressive ways are in this area, for example, the molecular gastronomy, which combines new scientific knowledge of science with traditional culinary arts, or the growing trend of interest in healthy eating in conjunction with an intense gastronomic experience. This paper describes the issues and the situation about organic food and their possible use in the catering trade as an opportunity to expand the menu.

The introduction describes organic farming and attempts to balance the fundamental differences between organic and conventional agriculture. It also indicates which way is better to get organic food. Then, is the familiar issue of additives, which are used in gastronomy and have potential negative effects on health. The last chapter provides the basic possibilities of organic food in catering establishments and their inclusion in the diet. The main source of the information for creating the text has been working with literary sources, the relevant legislation and the author's own findings. The method that was used is empirical research, based on work with existing data and descriptive way, the author draws conclusions. Just in conclusion are presented and summarized the possibility of using organic products in gastronomy.

If we thought about organic farming as something new, it is a mistake, the concept of management of the

Klara Vaclavinkova, Mgr., Assistant Professor, Department of Tourism, School of Business Administration in Karvina, Silesian University in Opava.

Correspondence concerning this article should be addressed to Klara Vaclavinkova, Havrani 3/1029, Havirov-Bludovice, 736 01, Czech Republic. E-mail: vaclavinkova@opf.slu.cz. 
natural world that is friendly and thinks of the future, is as old as humanity itself. If we look into the near past, we realize that at the beginning of last century, people were considering the use of chemicals and fertilizer for damaging nature. Thus, a movement of organic farmers gradually expanded throughout the world.

The main idea of organic agriculture is based on the philosophy of a holistic understanding of nature (holos = whole). Nature is uniform in its total. The people are as a part of nature and in terms of its laws which is equal to other animals. One should not attempt to forcibly dominate nature, but has to act in concert with it based on moral and ethical responsibility for maintaining the multilateral forms of life on the Earth (Moudrý, 1997).

\section{The Main Objectives of Organic Farming}

- to protect nature and the natural environment, and produce high quality organic food;

- to improve soil fertility and its ecological function and avoid all the pollution coming from this business;

- to produce food of high nutritional value, good looks, and quality of taste;

- to maintain the rural population and the cultural tradition of the agricultural landscape;

- to enable farmers to have social development and job satisfaction;

- to reduce the use of non-renewable energy sources, rejecting artificial mineral fertilizers, and plant protection;

- to create conditions for farm animals that meet their needs and enable them to have natural behavior (e.g., movement outside and their healthy growth).

Another advantage of green economy is the creation of new jobs in agriculture. Ecological goods usually employ more people than industrial by 10-20 percent. Primarily, human resources were carried out various activities which caused the limited mechanization and especially environmental pollution.

\section{Conventional Agriculture}

Conventional agriculture is fully concentrated on the economic component of agriculture which is the maximum yield. The aim is to maximize profits regardless of the ecosystem.

Growing plants and conditions:

- Special varieties are grown (sometimes even genetically modified organisms) and varieties resistant to pests;

- Fertilizers are applied to the maximum number (mainly mineral). As a result of environmental pollution and ground water and raw material itself, this is burdened with residues of the elements contained in the fertilizer-phosphorus, nitrogen, sulfur, etc.;

- Because of the limited number of passes on the field in terms of farming techniques, poorly aerated soil is a natural process of renewal;

- This system does not deal with changes in the environment, especially in agroecosystems;

- Violation of soil fertility and other chemical properties, so soil is not permeable to air, water, and maintained minerals that serve as food for soil benthos;

- As a result of ablation occurs, which caused fertilizer pollution of groundwater and eutrophication of water bodies;

- Frequent monoculture reduces yields. There is no crop rotation, thereby, depleting the soil.

Livestock farming in conventional agriculture:

- The goal is maximum and cheaper production of meat and other raw materials of animal origin (eggs and 
milk);

- They do not take into account the natural behavioral needs of animals, the right space is limited, separated by sex;

- Method of farming is closed (in the stable with little movement);

- For poultry is typical farming of cage or grids;

- Risk of residues of antibiotics that are commonly administered to extensive farms.

\section{Organic Food}

Organic product can be described as a raw material of animal or vegetable origin obtained in organic farming, a method of farming that does not use chemical fertilizer, chemical sprays, and artificial substances, and other animals are not given antibiotics, it is not feed on meat and bone meal and artificially stimulates their growth. It follows that it is management with a positive attitude towards nature and animals. They may take the form of vegetables, fruits, legumes, cereals, milk, eggs, or animals at a time. While organic products are available in retail units, but there are still very few in present. The best way is to get customers to buy them at the source of the organic food, or to organic farms (Moudrý, 1997).

Organic food is made from organic products as provided for in Council Regulation 2092/91 EC Treaty and Act No. 242/2000 Coll. In organic agriculture, it issued a certificate of organic origin. They are characterized by higher quality, strong taste, and greater nutritional value.

Basic possibilities of assessing the quality of organic food:

- Nutritional value: A higher content of vitamins, enzymes, minerals, balanced ratio of protein and fat;

- Hygiene value: A lower incidence of contaminants such as nitrates, pesticides, herbicides, heavy metals, etc.;

- Technological value: Better shelf life, lower storage losses, lower gluten content, etc.;

- Sensory value: It is lower, the products are not so nice, colorful and have fragrant flavor as natural products. Wildlife, however, prefer to forage on green vegetation (Stříbrná \& Mikula, 2003).

\section{Additives in Food}

Now, people are beginning to pay more attention to the issue of adding additives to food. With the growing interest of people concerning on healthy eating, consistent with their growing interest in what they eat and what the food contains, people increasingly prefer the new directions in nutrition, among them, of course, include organic food consumption and preferences. Gaining in importance as the "slow food", which is the de facto opposite of "fast food". When such people's emphasis is that the food was accepted in calm, slow and the possibility to enjoy all the tastes and smells, what it can offer.

Additives are substances, that regardless of their nutritional value, generally, which do not as a food or as a characteristic ingredient of food. Additives are added to food during production, processing, treatment, packaging, transport, or storage, then additives or their by-products become or may become part of the food ${ }^{1}$.

The food additive is a substance not normally consumed as food and not normally used as a characteristic ingredient of food whether or not it has nutritive value, the intentional addition to food for a technological purpose in the manufacture, processing, preparation, treatment, packaging, transport, or storage, or is likely to have resulted in it or its by-products directly or indirectly to be a component of food ${ }^{2}$.

\footnotetext{
1 Act No. 110/1997 Coll. The Ministry of Agriculture, Food, and Tobacco Products.

2 Regulation of the European Parliament No.1333/2008 on food additives.
} 
Additives are added to food and drink, to impart desirable flavor characteristics (acidity, sweetness, saltiness, and bitterness), consistency, and color. Some additives increase the durability, prevent mold and bacteria growth, further agglomeration remove or replace certain ingredients such as sugar and fat. Some additives improve the sensory properties of foods.

Gelling, thickening, and stabilizing agents ensure that the food gets the desired texture and consistency. Emulsifiers and stabilizers enable the production of foods containing fat and water.

Additive may be used to produce:

- if there is evidence of technological need for its use and purpose cannot be achieved by other means;

- if the quantity used is not a risk to consumers;

- to maintain the nutritional value of foods, with the deliberate reduction of nutritional value which shall be permitted only if such food is not an essential component of a normal diet or when the use of additives are necessary for manufacture of foodstuffs for particular nutritional uses;

- to increase food shelf life or improve its organoleptic properties, if you change the quality of food ${ }^{3}$.

Additives can be used to produce:

- unprocessed food;

- honey;

- non-emulsified grease and oil, butter;

- whole milk, semi-skimmed and skimmed milk, pasteurized or sterilized, including high temperature-treated, and cream, flavored fermented dairy products with live cultures;

- natural mineral water and bottled spring water;

- with the exception of coffee flavored instant coffee and coffee extracts;

- non-flavored tea;

- sugar;

- dried pasta, excluding gluten-free pasta or pasta intended for hypoproteic diet;

- unflavored except sterilized buttermilk ${ }^{4}$.

\section{Additives' Negative Impacts on Health}

Even though, there are all additives in food prior to use in the complex process through inclusion of permitted substances, there are many experts who deny their safety and recommend the adoption of additives in food in limited quantities. The main problem is how to test the healthy additives. Testing of additives is usually carried out on animals, mainly rodents. Food requirements are different in rodents and other humans. It is further noted that the excretion of xenobiotics in experimental animals is far faster than it is in humans (Syrový, 2008).

Children's hyperactivity shows like an increased agility and concentration disorders. Children with hyperactivity are moody and restless, suffer from sleep disorders and problems with learning. Children's body is very sensitive to external influences. It is assumed that in children, the additives may show the most adverse effects. The reason is obvious that the children consume more food than adults and their internal organs must deal with relatively higher doses of additives. Legislation on food additives on children remembered only in

\footnotetext{
3 Regulation No. 4/2008 Coll. Ministry of Health of January 3, 2008, laying down the types and conditions of use of additives and solvent extraction in food production.

${ }^{4}$ Regulation No. 4/2008 Coll. Ministry of Health of January 3, 2008, laying down the types and conditions of use of additives and solvent extraction in food production.
} 
connection with child nutrition, but the presence of the legislation is very limited. Other food products which consumed mostly by children have adjusted ADI, and therefore may contain the same amount of additives such as food intended for adults. Increased intake of additives in children is mainly caused by eating sweets, candies, chewing gum, and soft drinks. But these products are often have better sales because they have more colors and sugar. The coloring sweets are often used synthetic dyes because they are cheaper and have more intense color. The European Union has prepared a list of most suspicious dyes. This is the E 102, E 104, E 110, E 122, E 124, and $\mathrm{E}$ 129. The usage of these substances in foodstuffs must be in accordance with the European Parliament and Council No. 1333/2008 after July 20, 2010, on the packaging that may have an adverse effect on children's activity and attention (Babička, 2010).

The main symptoms of intolerance and hypersensitivity to food additives include skin conditions, digestive problems, and neurological problems. Skin reactions are manifested as hives, eczema, swelling, or itching. The digestive problems are associated with abdominal pain, bloating, diarrhea, nausea, and vomiting. The neurological manifestations include headache, malaise, muscle pain, depression, moodiness, and visual disturbances (Vrbová, 2001).

The use of additives in gastronomy:

The gastronomes can most affect the quality of their food. Based on a careful selection of raw materials, they are able to create food that is nutritionally balanced and healthy. The gastronomy additives get through food. Today, the reality is that restaurants use different types of preparations and flavoring agents. These products are added additives to maintain and increase the durability of the taste qualities. Semi or stocks attract restaurant price, speed, and simplicity. For completeness, we list the best known groups of additives applicable in gastronomy.

Condiments:

- stocks, artificial seasoning and liquid spices into the soup;

- soy and worcestershire sauce;

- marinades.

Marinades and spice blends are enriched with "soften" that prevent weight loss during cooking of meat. Negative components of flavors are glutamates, preservatives, and large amounts of salt.

Intermediate products:

The word "konvenience" is borrowed from the English words of ease, comfort, and convenience. The English word is "stock". The stocks are products that are processed in some way from the manufacturer. The development trends in the use of semi-gastronomy also contribute to constantly improving methods of food packaging. In the market, we can buy different kinds of semi-finished products. A half-processed product requires short cooking. This is the broth in a nutshell, dried sauces and juices, soups, and frozen pre-fried annex. Among the products ready for use it includes meals or other vacuum-packed. The following are considered as stock products intended for direct consumption, such as bread, dairy products, flour, butter, etc..

With the advantage of the semi-reduced preparation time and with preservative agents and long shelf life, the disadvantage may be the loss of freshness and vitamins of the food. Using the stock of the food reduces the total value of food, both biological and sensory aspects. In preparation of organic-food is absolutely unacceptable to use any product containing the additive.

In Europe, it is currently a trend to abandon the system of agriculture-as it has been shown to limit the number of passes in the field, increase the chances of survival of some microorganisms and pathogens and 
deteriorating soil physical properties (Królová, 2009).

\section{Theory and Hypothesis}

The main area of research for the article is to determine whether there is an increase of organic farmers and an increase of production in the Czech Republic organic food.

HA1: Numbers of farmer focused on production of organic food has increased since 2001.

HA2: The production of organic food increases.

HA3: It is possible to use organic foods for enrichment menu in restaurants.

The method that was used is empirical research, and based on work with existing data and descriptive way, the author draws conclusions. Just in conclusion are presented and summarized the possibility of using organic products in gastronomy. Basic information is from available literature sources, the author studies them and creates some kind of suggestions for practice. Problems of implementation in current organic dish offers restaurants currently still a novelty, although the phenomenon of organic food in our market is already known for some time.

At the end of 2009, 2,689 organic farmers worked in farm and there have 501 organic food producers. During 2009, the number of organic wine and fruit industry, area of orchardist organically managed orchards was 3,678 ha, area of vineyard was 645 ha. Farming organically farmed soil increased to 398,407 ha, which represents $9.38 \%$ of total agricultural land. More than $25 \%$ of agricultural land management practices are applied to a favorable environment with the support of the agricultural politics. A positive trend is the increase in arable land in organic farming, which reaches more than 55,000 ha. Arable land in total agricultural land in organic agriculture is only during the year increased from $11 \%$ to $13 \%$. This confirms the hypothesis HA1.

For an overview in Table 1, the author presents the development of organic farming land area since 1990.

Table 1

The Development of Organic Farming Land Area Since 1990

\begin{tabular}{lccc}
\hline Year & Total number of companies & \multicolumn{2}{l}{ The area of agricultural land in } \\
organic farming (ha) & Percentage of agricultural land \\
\hline 1990 & 3 & 480 & - \\
1991 & 132 & 17,507 & 0.41 \\
1992 & 135 & 15,371 & 0.36 \\
1993 & 141 & 15,667 & 0.37 \\
1994 & 187 & 15,818 & 0.37 \\
1995 & 181 & 14,982 & 0.35 \\
1996 & 182 & 17,022 & 0.40 \\
1997 & 211 & 20,239 & 0.47 \\
1998 & 348 & 71,621 & 1.67 \\
1999 & 473 & 110,756 & 2.58 \\
2000 & 563 & 165,699 & 3.86 \\
2001 & 654 & 217,869 & 5.09 \\
2002 & 721 & 235,136 & 5.50 \\
2003 & 810 & 254,995 & 5.97 \\
2004 & 836 & 263,299 & 6.16 \\
2005 & 829 & 254,982 & 5.98 \\
2006 & 963 & 281,535 & 6.61 \\
2007 & 1,318 & 312,890 & 7.35 \\
\hline
\end{tabular}


(Table 1 continued)

\begin{tabular}{llcc}
\hline Year & Total number of companies & $\begin{array}{l}\text { The area of agricultural land } \\
\text { in organic farming (ha) }\end{array}$ & Percentage of agricultural land \\
\hline 2008 & 1,946 & 341,632 & 8.04 \\
2009 & 2,689 & 398,407 & 9.38 \\
2010 & 3,517 & 448,202 & 10.55 \\
$\mathbf{2 0 1 1}$ & $\mathbf{3 , 9 2 0}$ & $\mathbf{4 8 2 , 9 2 7}$ & $\mathbf{1 1 . 4 0}$ \\
\hline
\end{tabular}

Note. Source: Retrieved March 15, 2012, from http://eagri.cz/public/web/file/148890/statistika_zakladni_31_12_2011.doc.

\section{Legislation Describing Organic Agriculture}

Each organic farmer must follow strict rules, based on the following legislation. It is Regulation 834/2007 on organic production and labeling of organic products and repealing Regulation (EEC) No 2092/91 and Act No. 242/2000 Coll. on organic agriculture. The Act, in relation to the directly applicable regulation of the European Communities conditions of organic farming and the related certification and labeling of organic products, organic food and other organic products, and exercise control and supervision of the observance of obligations related thereto (Królová, 2010).

Table 2

Comparison of Basic Statistical Indicators of Organic Farming

\begin{tabular}{|c|c|c|c|c|}
\hline & $\begin{array}{l}\text { December } \\
2010\end{array}$ & $\begin{array}{l}\text { 31, December } \\
2011\end{array}$ & $\begin{array}{l}\text { 31, The increase for } \\
\text { January-December } 2011\end{array}$ & $\begin{array}{l}\text { The increase for } \\
\text { January-December } \\
2011(\%)\end{array}$ \\
\hline Number of organic food producers & 626 & 646 & 20 & 3 \\
\hline Number of organic farms & 3,517 & 3,920 & 403 & 11 \\
\hline $\begin{array}{l}\text { The area of agricultural land in } \\
\text { organic farming (ha) }\end{array}$ & 448,202 & 482,927 & 34,725 & 8 \\
\hline $\begin{array}{l}\text { Share of organic farming in total } \\
\text { agricultural land (\%) }\end{array}$ & 10.55 & 11.40 & 0.85 & \\
\hline The acreage of arable land (ha) & 54,937 & 59,281 & 4,344 & 8 \\
\hline The area of permanent grassland (ha) & 369,272 & 398,060 & 28,788 & 8 \\
\hline Area of permanent crops (orchards) (ha) & 5,128 & 6,453 & 1,325 & 26 \\
\hline Area of permanent crops (vineyards) (ha) & 803 & 965 & 162 & 20 \\
\hline Area of permanent crops (hop) (ha) & 8 & 10 & 3 & 25 \\
\hline
\end{tabular}

Note. Source: Retrieved March 15, 2012, from http://www.eagri.cz/public/web/file/148890/statistika_zakladni_31_12_2011.doc.

\section{Foundation for Organic Agriculture}

Foundation for Organic Agriculture (FOA) - nonprofit organization was founded originally as a foundation in 1991 to develop and support organic farming in the Czech Republic, then in 1999, it was transformed into an endowment fund.

The task of FOA is to support research and development in organic farming and environmental protection and securing funding for these programs and projects.

In the Czech Republic, there is also the action plan for organic farming, which in 2015 will allow for the increase of agricultural land farmed in environmentally friendly mode from $10 \%$ to $15 \%$. Under this plan, in the years 2011-2015, the percentage should rise in the domestic organic food market to 3\%, but now it represents about $1 \%$. To achieve these objectives, the marketing support such as lead or increase public awareness of the 
benefits of organic farming.

As shown in Table 3, the number of producers of organic food is growing every year, which indicates that the sale and use of organic food in catering is possible. This confirms the hypotheses HA1, HA2, and HA3.

Table 3

Number of Organic Food Producers in the Years of 2001-2010

\begin{tabular}{lc}
\hline Year & Number of organic food producers \\
\hline 2001 & 75 \\
2002 & 92 \\
2003 & 96 \\
2004 & 116 \\
2005 & 125 \\
2006 & 152 \\
2007 & 253 \\
2008 & 422 \\
2009 & 497 \\
2010 & 626 \\
2011 & 646 \\
\hline
\end{tabular}

Note. Source: Retrieved March 15, 2012, from http://www.eagri.cz/public/web/file/148890/statistika_zakladni_31_12_2011.doc.

\section{Presentation of Options for Consumers of Organic Food}

Bio-clubs currently involved in many cities in the Republic, including Prague, Brno, and Teplice and their popularity is growing. They can be regarded as a Czech equivalent of English "organic buying groups" which are organizations of people who meet regularly in order to buy organic food, and by ordering food in large quantities directly from farmers, and these quality organic products are at affordable prices.

These clubs allow you to buy directly from nearby farmers. Food is thus guaranteed for the fresh and local goods. Another very important advantage is that the organic foods of the clubs are usually cheaper because there is no need to supply to supermarkets, which save most of the money. In bio-club, all the expenses for the goods will immediately deliver to the farmer. So they are available to get organic foods from farmers and organic food stores that are not commonly available in the markets. Members especially receive seasonal fruits and vegetables, dairy products or eggs from bio-clubs. Here are just offering an option for gastronomic equipment operator, to be a member of bio-clubs.

Bio-clubs are usually non-profit. They have yet another dimension which saves nature and supports small organic farmers. Although, organic farmers have the possibility to use state subsidies, it is not helpful to them. The main problem is sales. Purchases give a small amount or pay little money. So a piece of quality products, do not get to supermarkets. Another hurdle is the European legislation-often compounded by the Czech. The EU regulation appears to be somewhat flexible, for example, distinguish between big and little traffic. With that Austria needs much more farms, meat processing, and milk on the place (Brožová \& Kaspříková, 2008).

Bio-clubs can be divided into formal and informal ones. Formal bio-clubs can take the form of civic associations or public benefit corporation. Formally founded bio-clubs are subject to statutory rules for the operation of food businesses. This is essentially in Act 110/1997 Coll. on foodstuffs and tobacco products, European Regulation 852/2004 on food hygiene and regulations on individual commodities (Brožová \& Kaspř́íková, 2008). 
Informal associations can then be friends who contact the farmers directly, from which they can subscribe to products in bulk organic quality.

Picking up the goods is then possible in several ways:

- The system packaged, or bio-box: Crates system is one of the fastest growing methods of distribution of fresh and seasonal products by producers without intermediaries, directly to end consumers. "The box" is a system where the farmer and usually greengrocer can regularly deliver cultivars in crates directly to customers. Based on the range of crates, there usually contain all kinds of vegetables and fruit, sometimes may contain dairy products, herbs, dried fruit, bread, pickles, and meat, farmers often add boxes to recipes and information on their crops that not only address our interest and curiosity, but also, through this method of sale, can bring a personal tone. They help to bridge the gap that had formed between the diners in cities and farmers in the country (Václavík, 2010);

- The food bank or pantry: Bio-club in large quantities to purchase perishable foods from smaller producers or local farmers. Members can then take as many as they needed. Given that the food collected from farmers in large packs, they are considerably cheaper than in stores;

- Surprise: One can order at the farmer supplies food for the entire season and bring the manufacturer to the customer what he/she was brought forth. This form is not suitable for service kitchens since it would require a degree of flexibility.

\section{Conclusions}

\section{Possibilities of Organic Food as Part of the Menu}

Business owner may choose to implement the food, which will include organic food. This decision should be preceded by information to determine whether all of the dishes to customers are interested in. Several tools of marketing research can be used.

Marketing research is the specification, collection, analysis, and interpretation of information, which serves as a basis for decisions in the process of marketing management (Kotler, 2007).

The obtained information can:

- formulate guidelines of marketing activities;

- evaluate the results;

- understand the market where the company operates or intends to do business;

- identify issues related to business in this market;

- identify opportunities that can occur on it.

The methods of marketing research include:

- polling;

- questionnaire;

- observation;

- experiment;

- psychological methods in marketing research.

The questionnaire:

It is considered to be the most typical and often used method of marketing research. It is based on verbal communication with persons surveyed - the respondents. Its aim is to find differences in needs, demands, judgments, and attitudes of respondents, and obtain information on the real facts. The advantage of polling is 
that, unlike other methods, the results are quantitatively quite easily processable. It should be taken into account, however, that attitudes and opinions of the respondents can not be measured merely by asking.

Polling is a method of collecting primary information based on direct (interview) or mediated (questionnaire) contact between researcher and respondent in accordance with generally advance the prescribed form of questions, which serves to unify and facilitate the processing conditions (Kotler, 2007).

By ways of contacting, the respondents can be divided into oral interviews (personal), writing (by mail), and telephone (Stávková \& Dufek, 2004).

The questionnaire is one of the most widely used tools to collect primary data. It represents a form with questions to which respondents are responsible or variants also include their responses. The questionnaire is needed to build properly, try and get rid of bugs before use - the piloting. The importance of the questionnaire is in four areas: collects information from respondents; the interview provides the structure, i.e., directs interview process; ensures a uniform standard for compiling the data matrix; and for the fourth, facilitates data processing (Kozel et al., 2006).

Based on the data, the owner can choose the food and then propose to include in the menu.

Through promotion of organic food could be introduce a special menu, but that should accompany with adequate promotion, or can be directly in the menu section to clearly define which is organic food, or through customer service, or an information leaflet on the alert. Menu should have a traditional composition, and should include an appetizer, main course, and dessert. All, of course, are exclusively from organic products.

The author also recommends the form of promotional material to highlight the customer benefits of eating organic product, and train personnel to be able to answer any questions.

Another way could be that organic food promotes special events where the customer is familiar with this area and invited to a social evening with a lecture on the issue of organic farming, followed by a tasting organic dish in the form of buffet. Of course, there should be have information of the origin of raw materials.

The problem may be the unavailability of necessary raw materials. Organic foods are generally more expensive. Of course, the supermarkets can buy a relatively wide range of organic products, but the price is significantly higher than the direct supply by the producer.

Problems of implementation in current organic dish offer restaurants currently a novelty, although the phenomenon of organic food in our market is already known for some time. The aim of this paper was to clarify the basic prerequisites for understanding the basic principles of organic farming, determine what were the key differences between traditional and organic farming gain and which has an access to raw materials for food production. Basic information should come from available literature sources, the author studies them and creates some kind of suggestions for practice.

The biggest problem solved in the hospitality industry is undoubtedly abundant use of different flavors, etc., which contain largely additives, and which are the most non-organic origin and represent our body burden. In preparation organic dish, it is a taboo to use the additives. Is it possible to use additives of natural origin such as carotenoid pigments and agar, a thickener, for example, one can already find it in organic quality.

Gastronomic service operation is the implementation of quality organic food in a great challenge and a major opportunity to improve reputation with customers. Many people today prefer organic food starts despite their higher price. And they are aware of health benefits for themselves, but also such an ethical perspective on livestock. The introduction and promotion organic dish can also be used as a competitive advantage. The operator can use the new means of promotion, organizing special events with organic dishes, to prepare a 
special menu or set aside an entire section in the menu just for these dishes. This area offers many opportunities and it would certainly place to think about incorporating this product into the normal menu restaurants.

\section{References}

Act No. 110/1997 Coll. The Ministry of Agriculture, Food and Tobacco Products, Act of The Czech republic, quoted on 5.11.2011.

Babička, L. (2010). Maso. Tanec kolem Éček, 1, 17-20.

Brožová, Ž., \& Kaspř́ková, L. (2008). Čerstvé potraviny na dosah: Založte si spřáteli bioklub. Brno: Hnutí DUHA.

Burešová, P. (2006). Přecitlivělost na potraviny. Retrieved from http://www.szpi.gov.cz/docDetail.aspx?prn=1\&baf=0\&nid=11325\&doctype=ART\&docid=1000140\&chnum=5\&inqResults $=11357$

Elliot, R. (1997). Vegetarian meals for students (1st ed.). London: Harper Collons Publishers.

Kotler, P. (2007). Marketing management (p. 784). Praha: Graha Publishing.

Kozel, R. et al. (2006). Moderní marketingový výzkum (p. 277). Praha: Grada Publishing.

Królová, K. (2009). Hygiena a výživa I.: distančni studijni opora (p. 116). Karviná: SU OPF.

Maradová, E. (2007). Výživa a hygiena ve stravovacích službách (p. 196). Praha: Tiskářské služby—Rudolf Valenta.

Ministerstvo, Z. (2009). Zpráva o stavu zemédělství ČR za rok 2009, zelená zpráva (p. 224). Praha: MS Polygrafie s.r.o.—Bělá pod Bezdězem.

Ministry of Agriculture of the Czech Republic. (2011). Retrieved March 15, 2012, from http://eagri.cz/public/web/file/148890/statistika_zakladni_31_12_2011.doc

Moudrý, J. (1997). Bioprodukty (p. 37). 1. vyd. Praha: Institut výchovy a vzdělávání Mze CZ.

Regulation No. 235/2010 Decree No. of 19 July 2010, which specifies the requirements for purity and identification of additives. Document on European Union, quoted on 5.11.2011.

Regulation No. 127/2008 Coll. of 1 April 2008 amending Decree No. 113/2005 Coll. on labeling of foodstuffs and tobacco products, as amended. Document on European Union, quoted on 9.10.2011.

Regulation No. 4/2008 Coll. Ministry of Health of 3 January 2008 laying down the types and conditions of use of additives and solvent extraction in food production. Document on European Union, quoted on 5.11.2011.

Regulation No. 319/2007 Coll. of 30 November 2007 amending Decree No. 54/2002 Coll. laying down the health requirements for identity and purity of food additives. Document on European Union, quoted on 10.11.2011.

Regulation No. 113/2005 Coll. of 4 March 2005 on the labeling of foodstuffs and tobacco products.

Regulation No. 53/2002Sb. Ministry of Health of 29 January 2002 laying down the chemical requirements for the health of individual foods and food raw materials, conditions of use of additives, processing aids and food supplements. Document on European Union, quoted on 5.11.2011.

Regulation No. 54/2002Sb. Ministry of Health of 29 January 2002 laying down the health requirements for identity and purity of food additives. Document on European Union, quoted on 30.9.2011.

Regulation of the European Parliament No. 852/2004 on food hygiene. Document on European Union, quoted on 5.11.2011.

Regulation of the European Parliament No. 178/2002 laying down general principles and requirements of food law, establishing the European Food Safety Authority and laying down procedures relating to food safety - Article 8, Article 18. Document on European Union, quoted on 15.11.2011.

Regulation of the European Parliament No.1333/2008 on food additives Document on European Union, quoted on 5.11.2011.

Reinhold, M., Hermann, G., \& Kessler, T. (2003). Restaurace a host (p. 604). Haan-Gruiten: Fachbuchverlag Pfannenberg.

Stávková, J., \& Dufek, J. (2004). Marketingový výzkum (p. 189). Brno: Mendelova zemědělská a lesnická univerzita v Brně.

Stř́brná , M., \& Mikula, P. (2003). Agroturistika a biopotraviny (p. 51). Praha: Ústav zemědělských a potravinářských informací.

Syrový, V. (2008). Víme, co jíme aneb průvodce, Éčky v potravinách (p. 130). Brno: Integrál.

Václavík, T. (2010). Kam pro bedýnky. Retrieved from http://www.Bio-info.cz

Vrbová, T. (2001). Vime, co jíme aneb prưvodce, Éčky v potravinách (p. 268). Praha: Ekohaus. 